\author{
Manuela PINZARI* - Mario PINZARI ${ }^{* *}$ - Valerio SBORDONI ${ }^{*}$
}

\title{
Egg laying behaviour, host plants and larval survival of Euphydryas aurinia provincialis (Lepidoptera Nymphalidae) in a Mediterranean population (central Italy)
}

\begin{abstract}
Riassunto: Deposizione delle uova, scelta delle piante ospiti e sopravvivenza delle larve di Euphydryas aurinia provincialis (Lepidoptera Nymphalidae) nell'area Mediterranea (Italia centrale).

In questo lavoro, sono riportati i risultati di uno studio di cinque anni sul campo finalizzato a individuare le piante nutrici delle larve e le loro preferenze alimentari e valutare quali segnali siano utilizzati dalle femmine per la deposizione delle uova in Euphydryas aurinia provincialis nell'area Mediterranea. Le femmine depongono su Gentiana cruciata, Scabiosa columbaria e Cephalaria leucantha e le larve si nutrono indifferentemente su tutte queste piante, ma anche su Lonicera caprifolium e, in laboratorio, su Gentiana lutea. Le femmine non mostrano alcuna preferenza per una specifica pianta ospite e le larve passano a nutrirsi dall'una all'altra pianta senza alcuna difficoltà. I fattori più importanti nel determinare la selezione della pianta ospite per l'ovideposizione sono la visibilità, l'accessibilità e l'esposizione solare delle piante. Lo stato vegetativo delle piante ospite è il fattore chiave che determina quale specie vegetale sia utilizzata dalle larve nei diversi stadi dello sviluppo durante il periodo pre- e post-diapausa. G. cruciata e C. leucantha, piante ospite di grandi dimensioni, sono fondamentali per la crescita e la sopravvivenza degli stadi larvali pre-diapausa (I-III instar), mentre sono del tutto inadeguate per nutrire le larve in primavera dopo la diapausa invernale a causa del loro ritardo nella ripresa vegetativa; invece le piante di S. columbaria, molto più abbondanti e in fase vegetativa sempre molto più avanzata rispetto a G. cruciata e C. leucantha, sono utilizzate in primavera dalle larve post-diapausa per completare lo sviluppo. $L$. caprifolium, seppur in misura minore per la minor diffusione e il relativo ritardo nello sviluppo dei germogli, svolge un ruolo analogo a $S$. columbaria. Il lavoro è completato da alcune considerazioni conclusive dedotte dalle osservazioni. Vivere in gruppo sembra essere evolutivamente selezionato sin dalla deposizione delle uova sulle piante più grandi; infatti, le femmine di E. aurinia provincialis se trovano uova deposte da un'altra femmina vi depongono a fianco o addirittura sopra. Nonostante la competizione trofica tra le larve, questo comportamento delle femmine risulta evidentemente vantaggioso ed aumenta il tasso di sopravvivenza dei nidi sulle piante più grandi. La vita gregaria di un numero maggiore di larve su una pianta di grandi dimensioni: nel periodo pre-diapausa, riduce i casi di starvation; durante la diapausa invernale, con nidi più robusti e più stabili permette una maggiore resistenza ai predatori e ai rigori invernali; nel periodo post-diapausa, permette una maggiore efficienza nella termoregolazione rendendo le larve indipendenti dalle basse temperature esterne.
\end{abstract}

\begin{abstract}
In this paper, we show the results of research that can inform conservation measures elsewhere in Europe for the endangered butterfly $E u$ phydryas aurinia. A five year field study was undertaken to identify the host plant preference of larvae of Euphydryas aurinia provincialis in the Mediterranean and which signals are used by females to lay their eggs. The females oviposit on Gentiana cruciata, Scabiosa columbaria and Cephalaria leucantha; the larvae feed on all these plants and additionally on Lonicera caprifolium in the wild and on Gentiana lutea in the laboratory. The females do not show any preference for a specific host plant and the larvae move from one species of plant to another without any difficulty. The most important factors in determining the female oviposition are the visibility, accessibility and sun-exposure of the host plants. The vegetative state of host plants is the key factor in larval use of plants during the pre- and post-diapause period. The large-sized host plants, G. cruciata and $C$. leucantha, are optimal for the growth and survival of the pre-diapause I-III larval instar, while they are unavailable to the larvae in Spring because of their delayed vegetative growth. The post-diapause larvae preferentially feed on plants of S. columbaria, and to lesser degree L. caprifolium, as they provide and abundant food source compared with $G$. cruciata and C. leucantha. The results also suggest that, there is an evolutionary advantage in large numbers of caterpillars feeding together, with the females of E. aurinia provincialis preferring to lay their eggs nearby or above egg batches laid previously by another female, and selecting large plants for oviposition. Despite the competition for food among caterpillars, the oviposition behaviour of females is advantageous and increases the larval survival rate on large plants. The gregarious larval behaviour provides several benefits during both pre-diapause period (avoiding starvation) and post-diapause period (efficiency in thermoregulation).
\end{abstract}

Key words: Euphydryas aurinia provincialis, Female host plant choice, Larval host plant, Larval web survival, Larval aggregation behaviour.

\section{INTRODUCTION}

The Marsh Fritillary butterfly Euphydryas aurinia (Rottemburg, 1775) has suffered a severe decline in most European countries during the 20th Century (Van Swaay \& Warren, 1999; Van Swaay et al., 2010). For this reason E. aurinia is listed in Annex II of the

\footnotetext{
*Manuela Pinzari, Valerio Sbordoni, Dipartimento di Biologia, Università di Roma Tor Vergata, Via della Ricerca Scientifica 1, 00133 Roma, Italy. E-mail: manuela.pinzari@uniroma2.it, valerio.sbordoni@uniroma2.it

${ }^{* *}$ Mario Pinzari, Dipartimento di Ingegneria, Università di Roma 3, Via della Vasca Navale 79, 00146 Roma, Italy. E-mail: mario.pinzari@uniroma3.it
} 
European Community Habitats and Species Directive (92/43/EEC) and is also given protection through the Bern Convention.

In Italy the Euphydryas aurinia species complex is represented by three taxa that were alternatively considered as species or subspecies depending on authors (Verity, 1950; Hartig, 1968; Prola et al., 1978; Balletto \& Cassulo, 1995; Parenzan \& Porcelli, 2006; Balletto et al., 2014a). These taxa are: i) aurinia (Rottemburg, 1775), occurring in wet meadows in the Po Plains, ii) glaciegenita (Verity, 1928), in alpine region of Northern Italy, and iii) provincialis (Boisduval, 1828), which is limited to the Maritime Alps and the Apennine Mountains (Balletto et al., 2014b). According to the most recent assessment (under Art. 17 of Habitat Directive) the conservation status of E. aurinia populations is judged to be "bad" in Central and Northern Europe, where suitable habitat has become strongly reduced in area and fragmented. In Italy, at least 12 populations of E. a. aurinia have become extinct because of habitat destruction (Bonelli et al., 2011). On the contrary, the conservation status of the Mediterranean and Alpine populations is "favourable" (Balletto et al., 2014b).

Most of the available information on ecology and biology of the E. aurinia species complex comes from E. a. aurinia in Western and central Europe where it has been studied in some detail for over a century (Ford \& Ford, 1930; Porter, 1981; Warren, 1993; 1994; 1996; Warren et al., 1994; Klemetti \& Wahlberg, 1997; Wahlberg, 2001; Anthes et al., 2003; Hula et al., 2004; Saarinen et al., 2005; Mazel, 2006; Peńuelas et al., 2006; Svitra \& Sielezniew, 2010; Porter \& Ellis, 2011). In contrast, very few observations on ecology and biology of this species have been carried out in the Mediterranean area. The first ecological observations on E. aurinia in the Mediterranean are reported by Verity (1950) and Jutzeler (1994) and only recently by Casacci et al. (2014). Verity describes E. aurinia provincialis as a butterfly that usually inhabits both marshy meadows in the forest glades and dry meadows. Jutzeler refers to his observations on caterpillars and their host plants from a Ligurian population. Casacci et al. (2014) reports the results on metapopulation dynamics and dispersal abilities of two populations of E. (a.) glaciegenita from NW Alps and $E$. (a.) provincialis from Northern Apennines, with mention of some larval food plants (Tab. 1).
The main purpose of this paper is to understand why the Mediterranean populations of E. aurinia in Central Italy are in a better state than elsewhere by looking at key aspects of its ecology and biology. In this research we looked at a population of E. a. provincialis in the Apennines of Central Italy with the aim of identifying: i) host plant preference by ovipositing females; ii) larval host plant preferences; iii) the interaction between larvae and host plants during their life cycle; and iv) the larval survival after winter diapause.

\section{MATERIALS AND METHODS}

Study animal. E. aurinia is univoltine butterfly with adults emerging from May and flying through June to July depending on altitude and microclimate. Eggs are laid in batches of 300 or more on the underside of the leaves of host plants (Kuussaari et al., 2004). The species has six larval instars (three pre-diapause instars and three post-diapause instars); in European populations, the first five instars are gregarious and the sixth instar is solitary. The first three instar larvae are pale-brown and then change colour during the moult from the third to the fourth instar, becoming jetblack. In the early stages, larvae feed gregariously within a communal silken web and move from a plant to plant as their host plants are consumed; fourth instar larvae do not feed prior to diapause and overwinter in a larval web (hibernaculum), usually close to the ground and incorporating a few dead leaves which are spun tightly together (Porter, 1981; 1982). When the fourth instar larvae emerge from the winter diapause they still show the gregarious behaviour and use basking behaviour as a way of thermo-regulating (Porter, $1981 ; 1982)$. Larvae start to disperse in their fifth instar and feed solitarily (Warren, 1996; Kuussaari et al., 2004). Finally they pupate close to the ground, usually on plant stems (Warren, 1996).

Study area. E. a. provincialis is a widespread species in the Central Apennines and in particular in Monti Reatini (data from Osservatorio per la Biodiversità del Lazio). The study population of $E$. a. provincialis in Central Apennines was discovered during previous survey work (Pinzari et al., 2010) on the Lepidoptera in the area surrounding Vallemare (Rieti, Lazio, Central Italy, Location WGS84: N42.4836 ${ }^{\circ}$-E13.1148 ${ }^{\circ}$ ). Here, the species occupies habitat patches in montane grassland and slopes, sometimes steep and rocky, within a mosaic of different habitats including wooded 
Tab. 1. Status of knowledge on host plants and larval host use in E. aurinia subspecies.

\begin{tabular}{|c|c|c|c|c|}
\hline $\begin{array}{l}\text { E. aurinia } \\
\text { subspecies }\end{array}$ & Egg laying & $\begin{array}{l}\text { Pre-diapause } \\
\text { I-III instar }\end{array}$ & $\begin{array}{l}\text { Post-diapause } \\
\text { IV-VI instar }\end{array}$ & Instar not specified \\
\hline \multirow[t]{10}{*}{ aurinia } & $\begin{array}{l}\text { Succisa pratensis } \\
\text { (Porter, 1981; Porter \& Ellis, } \\
\text { 2011; Anthes et al., 2003; } \\
\text { Sardet \& Betremieux, 2006; } \\
\text { Eeles, 2014) }\end{array}$ & $\begin{array}{l}\text { Succisa pratensis } \\
\text { (Porter, 1981; Sardet \& } \\
\text { Betremieux, 2006; Porter } \\
\text { \& Ellis, 2011; Botham et al., } \\
\text { 2011; Masek, 1987, } \\
\text { In: Konvicka et al., 2003) }\end{array}$ & $\begin{array}{l}\text { Succisa pratensis } \\
\text { (Porter, 1981; Porter \& } \\
\text { Ellis, 2011) }\end{array}$ & $\begin{array}{l}\text { Succisa pratensis } \\
\text { (Luckens, 1978; Betzholtz } \\
\text { et al., 2007; Casacci et al., } \\
\text { 2014). }\end{array}$ \\
\hline & $\begin{array}{l}\text { Scabiosa columbaria } \\
\text { (Sardet \& Betremieux, 2006) }\end{array}$ & $\begin{array}{l}\text { Scabiosa columbaria } \\
\text { (Sardet \& Betremieux, 2006; } \\
\text { Mazel, 2006) }\end{array}$ & $\begin{array}{l}\text { Scabiosa columbaria } \\
\text { (Lobenstein, 2008) }\end{array}$ & $\begin{array}{l}\text { Scabiosa columbaria } \\
\text { (Porter, 1981; Warren, 1993; } \\
\text { Mazel, 1984) }\end{array}$ \\
\hline & $\begin{array}{l}\text { Knautia arvensis } \\
\text { (Sardet \& Betremieux, 2006) }\end{array}$ & $\begin{array}{l}\text { Knautia arvensis } \\
\text { (Sardet \& Betremieux, 2006; } \\
\text { Mazel, 2006) }\end{array}$ & $\begin{array}{l}\text { Lonicera periclymenum } \\
\text { (Porter \& Ellis, 2011) }\end{array}$ & $\begin{array}{l}\text { Scabiosa comosa } \\
\text { (Wahlberg et al., 2001) }\end{array}$ \\
\hline & $\begin{array}{l}\text { Lonicera implexa } \\
\text { (Stefanescu et al., 2006) }\end{array}$ & $\begin{array}{l}\text { Lonicera periclymenum } \\
\text { (Warren, 1993) }\end{array}$ & $\begin{array}{l}\text { Gentiana cruciata } \\
\text { (Svitra \& Sielezniew, 2010) }\end{array}$ & $\begin{array}{l}\text { Knautia arvensis } \\
\text { (Porter, 1981; Mazel, 1982, } \\
\text { 1984; Mazel, 1977 } \\
\text { In: Jutzeler, 1994) }\end{array}$ \\
\hline & $\begin{array}{l}\text { Gentiana cruciata } \\
\text { (Sardet \& Betremieux, 2006; } \\
\text { Lobenstein, 2008) }\end{array}$ & $\begin{array}{l}\text { Gentiana cruciata } \\
\text { (Sardet \& Betremieux, 2006; } \\
\text { Svitra \& Sielezniew, 2010; } \\
\text { Lobenstein, 2008) }\end{array}$ & $\begin{array}{l}\text { Valeriana dioica } \\
\text { (Anthes, 2002) }\end{array}$ & $\begin{array}{l}\text { Gentiana cruciata } \\
\text { (Hafner, 2001 com. pers. } \\
\text { In: Anthes, 2002; Perru \& } \\
\text { Sardet, 2005; Mazel \& } \\
\text { Lutran, In: Jutzeler, 1994) }\end{array}$ \\
\hline & $\begin{array}{l}\text { Gentiana asclepiadea } \\
\text { (Anthes, 2002; Anthes et al., }\end{array}$ & $\begin{array}{l}\text { Cephalaria leucantha } \\
\text { (Mazel, 2006) }\end{array}$ & $\begin{array}{l}\text { Valeriana sambucifolia } \\
\text { (Betzholtz et al., 2007) }\end{array}$ & $\begin{array}{l}\text { Gentiana asclepiadea } \\
\text { (Ebert \& Rennwald, 1991, } \\
\text { 2003) In: Anthes, 2002) }\end{array}$ \\
\hline & & & $\begin{array}{l}\text { Menyanthes trifoliata } \\
\text { (Anthes, 2002; Anthes et al., } \\
\text { 2003) }\end{array}$ & $\begin{array}{l}\text { Gentiana lutea } \\
\text { (Rey et al., } 2004 \text { in Sardet \& } \\
\text { Betremieux, 2006) }\end{array}$ \\
\hline & & & & $\begin{array}{l}\text { Cephalaria leucantha } \\
\text { (Mazel, 1982, 1984; Mazel \& } \\
\text { Lutran, In: Jutzeler, 1994) }\end{array}$ \\
\hline & & & & $\begin{array}{l}\text { Valeriana officinalis } \\
\text { (Favretto 2009) }\end{array}$ \\
\hline & & & & $\begin{array}{l}\text { Dipsacum fullonum } \\
\text { (B. Gillam, com. Pers. } \\
\text { In: Warren, 1993) }\end{array}$ \\
\hline \multirow[t]{3}{*}{ beckeri } & $\begin{array}{l}\text { Lonicera implexa } \\
\text { (Penuelas et al., 2006; } \\
\text { Stefanescu et al., 2006) }\end{array}$ & $\begin{array}{l}\text { Lonicera implexa } \\
\text { (Stefanescu et al., 2006) }\end{array}$ & $\begin{array}{l}\text { Lonicera periclymenum } \\
\text { (Junker \& Schmitt, 2010; } \\
\text { Warren, 1993) }\end{array}$ & $\begin{array}{l}\text { Lonicera periclymenum } \\
\text { (Warren et al., 1994) }\end{array}$ \\
\hline & & & $\begin{array}{l}\text { Lonicera implexa } \\
\text { (Stefanescu et al., 2006) }\end{array}$ & $\begin{array}{l}\text { Lonicera implexa } \\
\text { (Munguira, com. Pers; } \\
\text { Templado, 1975, in Warren, } \\
\text { 1993; Warren et al., 1994) }\end{array}$ \\
\hline & & & & $\begin{array}{l}\text { Lonicera etrusca } \\
\text { (Warren, 1993; Warren et al., } \\
\text { 1994; Kankare et al., 2005, } \\
\text { in Stefanescu et al., 2006) }\end{array}$ \\
\hline
\end{tabular}


areas, hedgerows, fields and less steep areas which are occasionally ploughed and cultivated. E. a. provincialis inhabits discrete habitat patches that differ in their larval host plants composition according to the following altitudinal zones: i) $1500-1300 \mathrm{~m}$, G. lutea L., G. cruciata L. and S. columbaria L.; ii) 1300-1000 m, G. cruciata, S. columbaria and L. caprifolium L.; iii) $1000-800 \mathrm{~m}, S$. columbaria and $L$. caprifolium or C. leucantha (L.) Schrad. ex Roem. \& Schult. We detected 13 habitat patches whose position, features and land use are indicated in Fig. 1; they are adjacent to each other and MRR sampling have shown (Pinzari M., unpublished data) that flying adults can be easily move between areas; in the study patches (Fig. 1) $C$. leucantha and G. lutea were absent. Additional observations were also carried out in habitat patches located outside the study area; they are at Monte Cagno and Villa Camponeschi, where the species and its host plants $G$. lutea and $C$. leucantha are recorded.

Adults of E. a. provincialis are regularly present within the habitat patches and absent in forests and scrub. They do disperse across other land parcels, such as agricultural areas and pastures, but these lack suitable host plants and offer little in the way of nectar sources. Caterpillars were observed only in patches of habitat with uncultivated steeply sloping rocky areas or road verges.

The field-work on adults of E. a. provincialis began in 2010 and has been continued up to 2015. Observations on larval stages started in 2012 and continued until 2015. A total of 77 days over three years were spent monitoring egg batches and larval webs, focusing on: eggs (from May to the end of June); prediapause gregarious phase (I-III instar on larval webs) (from May to September); diapause phase (IV instar in larval webs) (from September to mid-February); post-diapause gregarious phase (IV instar) (from midFebruary to mid-March); and solitary caterpillars (VVI instar) (from March to mid-April).

Laboratory observations on larval feeding behaviour were carried out in captivity in Rome in artificial rearing facilities indoors in February 2014 (19 February to 13 March) during eleven days and in April 2015.

Host plants. The biology of pre-imagined stages of E. aurinia complex has been studied by numerous scientists in Northern and Central Europe. There are far

Tab. 1. Segue dalla pagina precedente.

\begin{tabular}{|c|c|c|c|c|}
\hline $\begin{array}{l}\text { E. aurinia } \\
\text { subspecies }\end{array}$ & Egg laying & $\begin{array}{l}\text { Pre-diapause } \\
\text { I-III instar }\end{array}$ & $\begin{array}{l}\text { Post-diapause } \\
\text { IV-VI instar }\end{array}$ & Instar not specified \\
\hline \multirow[t]{4}{*}{ glaciegenita } & & & & $\begin{array}{l}\text { Gentiana clusii } \\
\text { (Geiger, } 1987 \\
\text { In: Warren, 1994) }\end{array}$ \\
\hline & & & & $\begin{array}{l}\text { Gentiana acaulis } \\
\text { (Geiger, } 1987 \text { In: Warren, } \\
\text { 1994; Casacci et al., 2014) }\end{array}$ \\
\hline & & & & $\begin{array}{l}\text { Gentiana kochiana } \\
\text { (Gerber, 1972, In: Anthes } \\
\text { 2002; Warren, 1996; Gerber, } \\
\text { 1972, In: Mazel, 1982) }\end{array}$ \\
\hline & & & & $\begin{array}{l}\text { Gentiana alpina } \\
\text { (Warren 1996) }\end{array}$ \\
\hline \multirow[t]{3}{*}{ provincialis } & & $\begin{array}{l}\text { Cephalaria leucantha } \\
\text { (Jutzeler, 1994) }\end{array}$ & $\begin{array}{l}\text { Lonicera etrusca } \\
\text { (Nel, 1983, in litt., } \\
\text { In: Mazel, 2006) }\end{array}$ & $\begin{array}{l}\text { Knautia arvensis } \\
\text { (Casacci et al., 2014) }\end{array}$ \\
\hline & & & $\begin{array}{l}\text { Cephalaria leucantha } \\
\text { (Jutzeler, 1994) }\end{array}$ & $\begin{array}{l}\text { Cephalaria leucantha } \\
\text { (Casacci et al., 2014) }\end{array}$ \\
\hline & & & $\begin{array}{l}\text { Centranthus ruber } \\
\text { (Jutzeler, 1994) }\end{array}$ & $\begin{array}{l}\text { Centranthus ruber } \\
\text { (Bromilov In: Verity, 1950) }\end{array}$ \\
\hline
\end{tabular}


fewer observations on the species complex in the Mediterranean area and in particular in Italy. For synthesis, in Tab. 1, all known host plants of E. aurinia subspecies are presented, with an indication where possible the corresponding use by pre- and post-diapause pre-imaginal stages. E. a. aurinia is the most studied sub-species and the host plants used by ovipositing females and by larvae are known. Several authors suggest that larvae feed exclusively on a single, main host plant; others state that the species can utilize a wide spectrum of host plants. Succisa praten- sis (Dipsacaceae) is the most important food plant of E. a. aurinia across the European species range and especially in the North; some other plants belonging to Dipsacaceae, Caprifoliaceae, and Gentianaceae families were also recorded for the species in Western and Southern Europe. E. a. beckeri is dependent to genus Lonicera for both oviposition and larval food plant. Prior to the current study, information on egg laying behaviour and female host plant preferences in E. a. provincialis was not clear; observations on caterpillars and host plants referred to populations in rocky

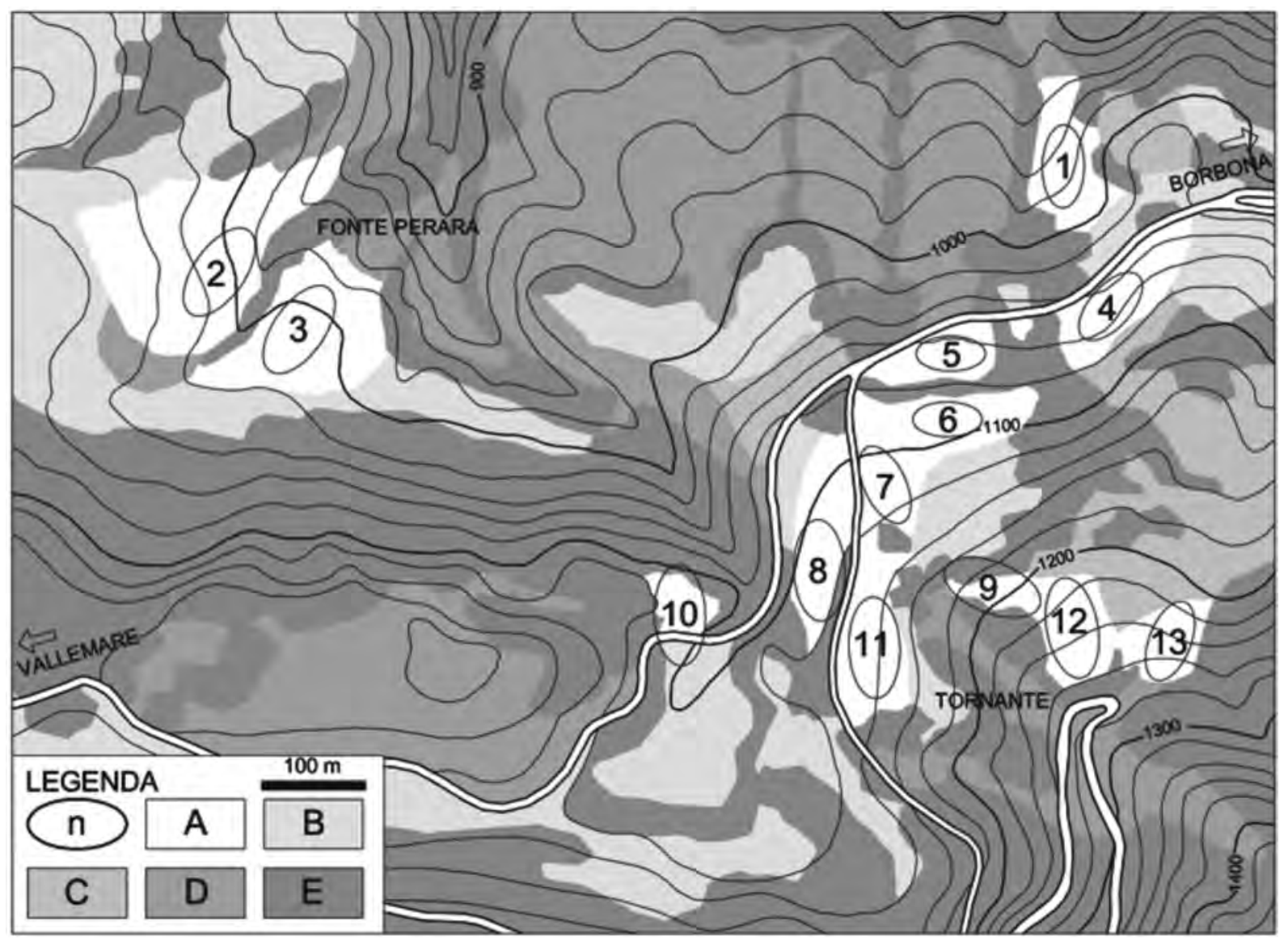

Fig. 1. Habitat and position of the habitat patches in the study area: 1, 4, Crossroads Santa Maria del Monte - Fonte Brignola; 2, 3, Fonte Perara; 5, 6, 7, 8, 11, along the path between the road to Santa Maria del Monte and Hairpin curve Mattano-Malepasso; 9, 12, 13, Hairpin curve Mattano-Malepasso; 10, Pian Mattano. The patch 14, Villa Camponeschi, is not included on this map due to its distance from the other localities ( $2 \mathrm{~km}$ from Fonte Perara). Features and land use of the study area: A) Semi-natural dry grasslands and scrubland facies on calcareous substrates, where adults of $E$. a. provincialis were recorded in past studies (Pinzari et al., 2010); B) cultivated areas for intense pasture and hay harvesting areas; C) thick scrubs; D) mineralized areas, erosion or with very little vegetation cover; E) high trees oak and beech forests; where adults of E. a. provincialis were absent. 
habitat in Southern France and in NW Italy (Liguria). Similarly, E. a. glaciegenita has been little studied and its biology is poorly known; existing observations suggest it uses species of Gentianaceae as food plants.

General. All study subjects (host plants, egg batches, larval webs) were marked by an alphanumeric code written on a stone that was positioned nearby. This enabled the relocation of plants at each sampling period and from year to year. All qualitative and quantitative observations have been documented with notes, photographs and short videos.

Female host plant choice. To identify the host plants of E. a. provincialis, we searched and quantified the target plant species, which were already known in literature for the E. aurinia complex species, and we examined these plants recording the presence of egg batches and larval webs with feeding caterpillars.

G. cruciata, L. caprifolium and S. columbaria were recorded in the study habitat patches, while $G$. lutea and C. leucantha were confirmed as host plants outside the study area. All individual plants of G. cruciata and C. leucantha were located across meadows and counted. S. columbaria was sampled along zigzag transects $\left(70 \mathrm{~m}^{2}\right.$ area, $35 \mathrm{~m}$ in length, $2 \mathrm{~m}$ in width). For this purpose twenty-seven transects were assessed in all habitat patches.

The presence of egg batches on host plants was recorded during twenty-three, variable length, zigzag transects. The use of variable length transects was done to allow for the heterogeneity in the distribution of host plants, especially $S$. columbaria and differing areas of sample locations.

In each transect we counted the egg batches (original and derived from larval webs) on each host plant to assess the number of egg batches laid in the studied habitats patches. The original site of egg batches from larval webs were determined by following the tracks of the webs spun by the caterpillars during their transfers from one host plant to another as they fed. The egg batches were recorded and the age of each batch, as determined by difference in colour, used to distinguish the eggs of different females on the same host plant. The eggs laid at different times by different females were easily recognizable by their different colour (bright yellow, freshly laid and changing from orange to purplish-brown, after a few days, Fig. 2). A female can lay two separate egg batches on the same plant and to avoid over estimation we considered all eggs with same colour as laid by the same female.

Using the field data we calculated for the all earlier stages (from eggs to pre-diapause larval stages) the plant occupancy rate, as the ratio between the number of plants with egg batches (original and derived from larval webs), and the number of the host plants examined along any transect.

Larval web survival and host plant phenology. To detect the role of host plants in larval survival we monitored the larvae behaviour and the larval webs during pre-winter and spring phase for three generations, focusing our attention on the growth characteristics of the host plants in the study area. The vegetative status of the host plants and surrounding vegetation was systematically recorded with photos, short notes and videos; this was schematically shown in Fig. 3A-C. We want to emphasize that $C$. leucantha, reported in Fig. 3 together with the other host plants, does not exist in the same place with G. cruciata; $C$. leucantha is limited to a rocky slope in a small habitat patch nearby Villa Camponeschi.

The pre and post-diapause larval webs were counted at every visit in each locality recording the presence/absence and documenting location by photos. For the post-diapause phase we counted both larval webs (IV instar, gregarious stage) and solitary larvae (V-VI instar). We calculated the survival rate of the larval webs as the ratio between the number of larval webs surviving the winter and the number of larval webs recorded before winter diapause.

Post-diapause larval host plant choice. To detect the larval host plant affinity of $E$. a. provincialis and the use of each host plant by V and VI instar larvae, we observed and counted the larval webs that overwintered and survived and the activities of gregarious (without webs) and solitary caterpillars in the study area along zigzag transects in all study habitat patches. In spring we observed the larval webs marked before winter and gregarious caterpillars (IV instar) behaviour, we then looked at the activity of solitary caterpillars. The time for each activity was assessed in proportion to the percentage of solitary caterpillars found in a specific activity. The field data were recorded when the weather was dry and sunny as this was when larvae were active.

The behaviour of the solitary caterpillars was 

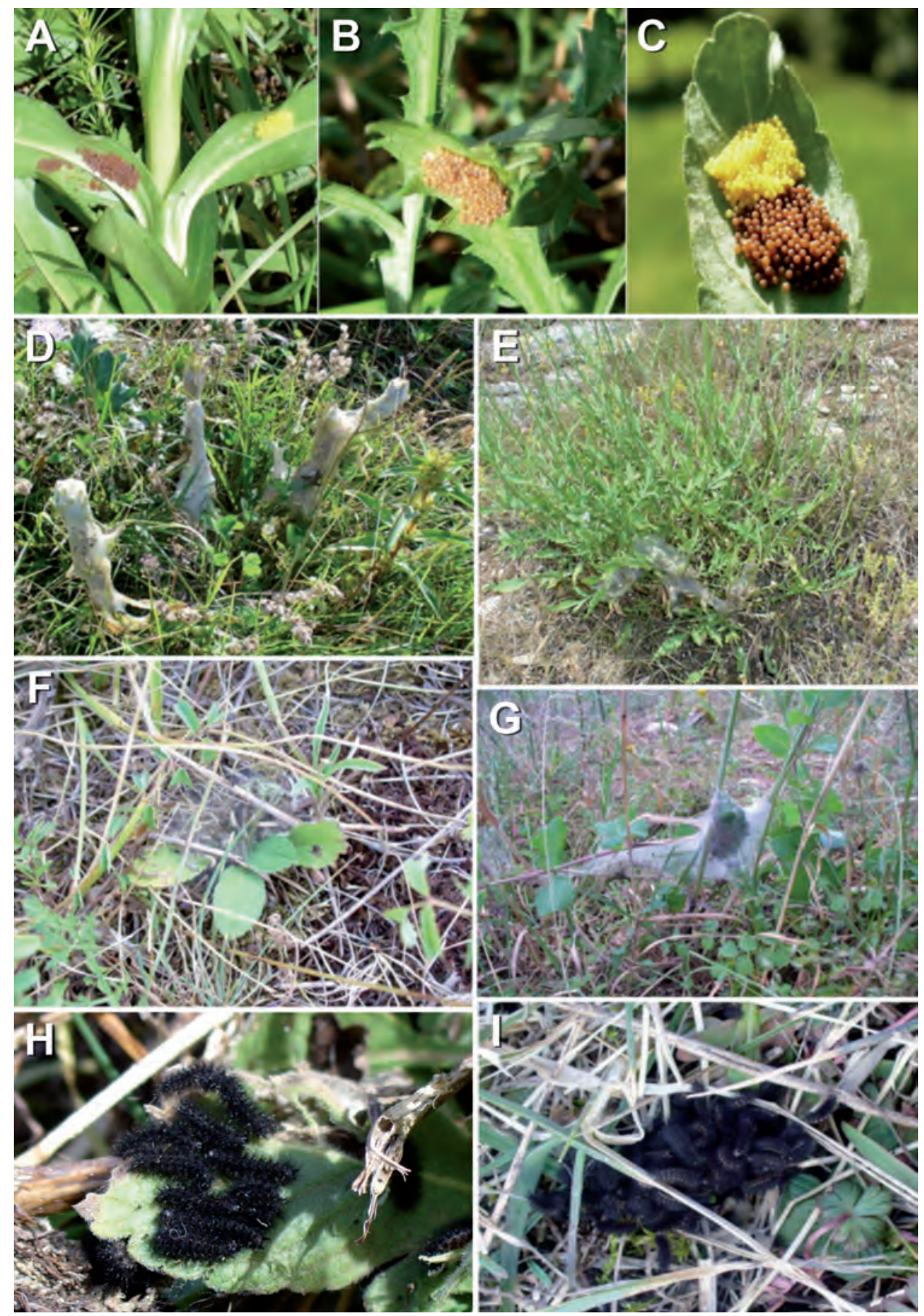

Fig. 2. Eggs and larval stages of E. a. provincialis on host plants: A) double deposition on G. cruciata; B) single deposition on C. leucantha; C) double deposition on the same leaf of S. columbaria; D) pre-diapause nest (II instar larvae) on G. cruciata; E) pre-diapause nest (I instar larvae) on C. leucantha; F) pre-diapause (II instar larvae) on S. columbaria; G) pre-diapause nest (II instar larvae) during transfer from $S$. columbaria to prostrate stems of L. caprifolium; H) and I) behavior of gregarious larvae of IV instar after winter diapause: When it was sunny, larvae arranged more or less parallel and in a single layer closing ranks as possible $(\mathrm{H})$; when there was no sun, larvae piled up on each other in a more compact manner possible (almost spherical) (I). 

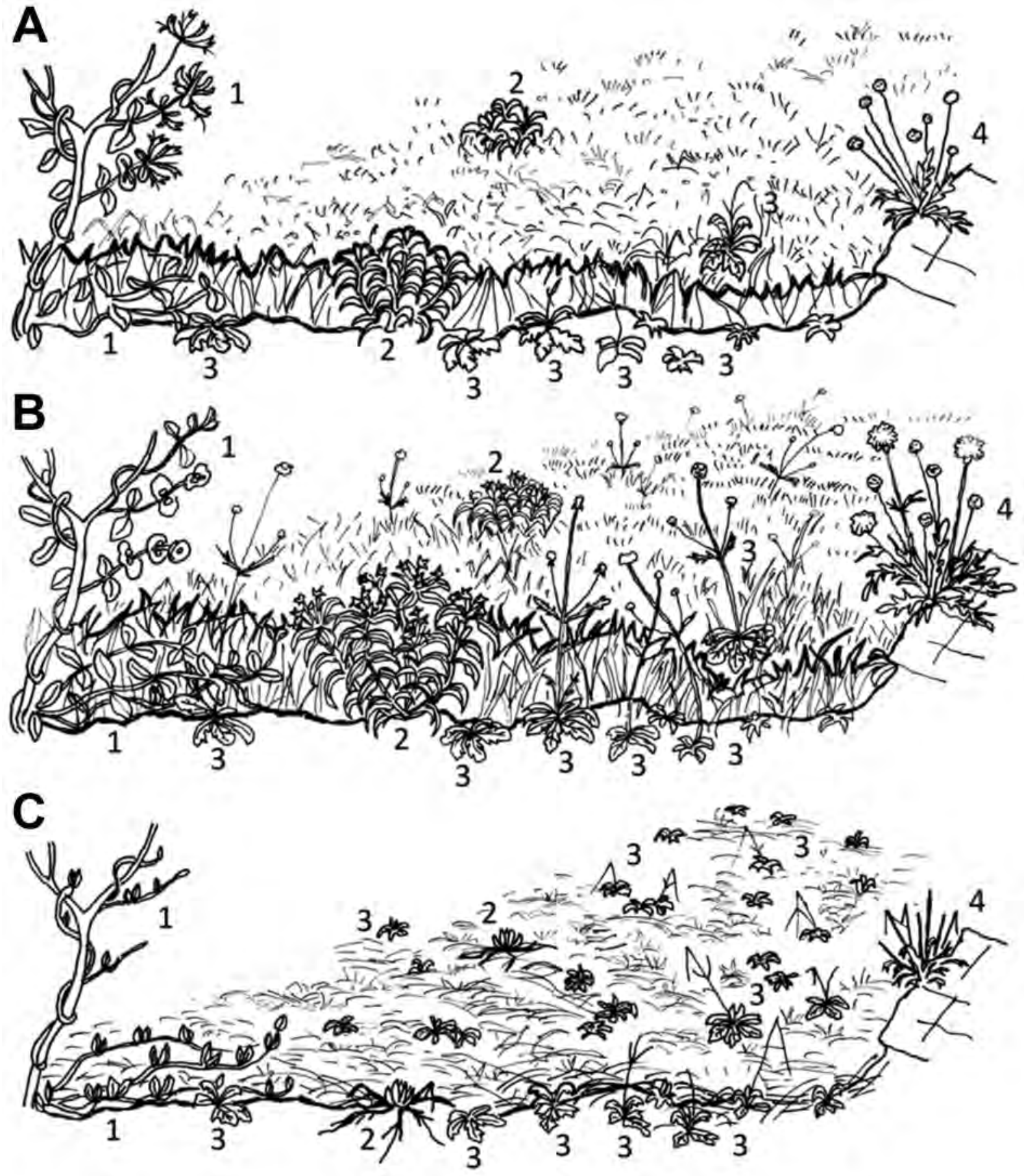

Fig. 3. Vegetation structure and host plants status during during larval stages in E. a. provincialis. A) Egg laying and pre-diapause period; B) diapause; C) post-diapause period. 1) Lonicera caprifolium; 2) Gentiana cruciata; 3) Scabiosa columbaria; 4) Cephalaria leucantha. This scheme reports all host plants present in the study area but G. cruciata and C. leucantha do not coexist in any patch. 
recorded against three behavioural categories (feeding, moving and dorsal basking). In the feeding category we recorded which host plant larvae were using.

To assess how the larvae of E. a. provincialis can switch feeding between different host plants we carried out feeding tests in laboratory on larvae of each stage. The feeding tests were carried using 50 larvae from a larval web on Gentiana cruciata collected in February 2014. During these tests the host plants $S$. columbaria, L. caprifolium, C. leucantha and G. lutea were offered to caterpillars by random plant rotation. Additionally, Plantago sp., reported in literature as host plant of E. a. aurinia, and abundant in the study area, was also tested during feeding experiments.

Observations on larval stages in captivity. To distinguish the instar of solitary caterpillars of $E$. $a$. provincialis observed in the wild populations we col- lected a sample of 27 larvae from natural populations and their growth was monitored up to pupal stage in captivity.

\section{RESULTS}

Host plants. In the study area we recorded three species that were already cited as host plants for $E$. aurinia species complex in other countries. They were S. columbaria, L. caprifolium and G. cruciata. A few kilometres away from the study area $C$. leucanth $a$ and G. lutea, were also found (see below). The plants of S. columbaria were abundant in all habitat patches, but with a patchy distribution (Tabs. 2 and 3).

This is in contrast to the very low density of $S$. columbaria in the cultivated and recently ploughed areas. The plants of G. cruciata were located in both meadow and scrub in all habitats patches, but they were uncommon and sparsely distributed (Tab. 4). The

Tab. 2. Records on single and multiple egg depositions in the surveys 2012-2013, 2013-2014, 2014-2015 and $2015-2016$.

\begin{tabular}{|c|c|c|c|c|c|c|c|c|}
\hline & \multirow[t]{2}{*}{ Patches } & \multicolumn{4}{|c|}{ Egg batches per plant } & \multirow{2}{*}{$\begin{array}{c}\text { Plants with } \\
\text { eggs } \\
\left(\mathrm{D}=\mathbf{N}_{\mathrm{s}}+\mathbf{N}_{\mathrm{d}}+\mathbf{N}_{\mathrm{t}}\right)\end{array}$} & \multirow{2}{*}{$\begin{array}{l}\text { Plants } \\
\text { (P) }\end{array}$} & \multirow{2}{*}{$\begin{array}{c}\text { Plant } \\
\text { occupancy } \\
\text { (D/P) } \%\end{array}$} \\
\hline & & Single $\left(\mathbf{N}_{\mathbf{s}}\right)$ & Double $\left(\mathbf{N}_{d}\right)$ & Triple $\left(\mathbf{N}_{\mathrm{t}}\right)$ & Egg masses $(\mathbf{N})$ & & & \\
\hline \multirow[t]{11}{*}{ Gentiana cruciata } & 4 & 0 & 1 & 0 & 2 & 1 & 1 & 100 \\
\hline & 5 & 1 & 2 & 0 & 5 & 3 & 7 & 43 \\
\hline & 6 & 2 & 0 & 1 & 5 & 3 & 5 & 60 \\
\hline & 7 & 10 & 2 & 1 & 17 & 13 & 14 & 93 \\
\hline & 8 & 4 & 1 & 0 & 6 & 5 & 14 & 36 \\
\hline & 9 & 2 & 1 & 0 & 4 & 3 & 5 & 60 \\
\hline & 10 & 1 & 0 & 0 & 1 & 1 & 2 & 50 \\
\hline & 11 & 2 & 2 & 1 & 9 & 5 & 6 & 83 \\
\hline & 12 & 2 & 1 & 0 & 4 & 3 & 7 & 43 \\
\hline & 13 & 2 & 3 & 0 & 8 & 5 & 9 & 55 \\
\hline & Tot. $(\%)$ & $26(43)$ & $13(22)$ & $3(15)$ & $61(100)$ & 42 & 70 & 60 \\
\hline \multirow[t]{3}{*}{ Scabiosa columbaria } & 1 & 9 & 0 & 0 & 9 & 9 & 203 & 4 \\
\hline & 2 & 1 & 1 & 0 & 3 & 2 & 288 & 1 \\
\hline & Tot. (\%) & $10(83)$ & $1(17)$ & 0 & $12(100)$ & 11 & 491 & 2 \\
\hline \multirow[t]{2}{*}{ Cephalaria leucantha } & 14 & 5 & 0 & 0 & 5 & 5 & 18 & 28 \\
\hline & Tot. $(\%)$ & $5(100)$ & 0 & 0 & $5(100)$ & 5 & 18 & 28 \\
\hline
\end{tabular}

Habitat patches: 1, 4, Crossroads Santa Maria del Monte - Fonte Brignola; 2, 3, Fonte Perara; 5, 6, 7, 8, 11, along the path between the road to Santa Maria del Monte and Hairpin curve Mattano-Malepasso; 10, Pian Mattano; 9, 12, 13, Hairpin curve Mattano-Malepasso; (Fig. 1); 14, Villa Camponeschi (see the location in Pinzari et al., 2010). 
robust growth from of G. cruciata meant that plants were clearly visible above the general herbaceous vegetation during butterfly flight period. In grazed meadows their visibility was increased due to their unpalatability for livestock (Fig. 3A). In the areas where adults of E. a. provincialis fly (Pinzari et al., 2010) G. cruciata was only present in south-faced meadows above an altitude of about $1000 \mathrm{~m}$. L. caprifolium was usually observed as a climber on scrub, or prostrate on the ground in the edge of the meadows, and occurred across all habitat patches in the study area (Fig. 3). The plants of C. leucantha (thirty-two plants) were $2 \mathrm{~km}$ from the study area on very steep rocky slopes on the edge of a short segment of paved road between the built-up areas of Villa Camponeschi and Laculo $(1000 \mathrm{~m})$. In this xerothermic habitat, where $C$. leucantha typically grows, adults of $E$. $a$. provincialis do occasional find this host plant as they fly between habitat patches. Egg batches and/or larval webs were found on G. cruciata, S. columbaria, $L$. caprifolium and C. leucantha (Tabs. 2-4), whilst no eggs or larvae were observed on G. lutea in the wild.

Frequent mention is made of Plantago sp. as a host plant in the scientific and popular literature. In the study areas the genus Plantago is abundant and represented by several species. However, no egg batches or feeding larvae were found on any Plantago spp. To the untrained eye, confusion is possible with
Melitaea cinxia (Nymphalidae) whose pre-diapause and post-diapause larval instar could be mistaken for E. aurinia. In laboratory, larvae of E. a. provincialis did not eat Plantago spp. plants offered during the feeding tests.

Eggs and host plant searching behaviour. The flight period of adults of $E$. a. provincialis extends from May to July in the study locality. Once mated, the females fly slowly through the meadows, nectaring and basking as well as searching for suitable oviposition sites. When searching for host plants, mated females performed very short flights, landing on plants and walking on the leaves as part of a meticulous and long inspection of the host plant (about $20 \mathrm{~min}$ on an area of not more than 9 $\mathrm{cm}$ in radius in one case). Once a plant is deemed suitable, the female stops on a selected leaf of the host plant, perches on the edge of the upper side of the leaf, and bends her abdomen to lay the eggs on the undersides of the lower and large outer leaves (Fig. 2A-C).

Over the period of the study we recorded sixtyone batches on G. cruciata (single $43 \%$, double $22 \%$ and triple $15 \%$ ), twelve on $S$. columbaria (single $83 \%$, double 17\%), and five on C. leucantha (all single batches) (Tab. 2). No egg batches were found on $L$. caprifolium and $G$. lutea. Many plants were without egg batches $(40 \%$ G. cruciata, $\mathrm{N}=28 ; 98 \%$ S. columbaria, $\mathrm{N}=480 ; 72 \%$ C. leucantha, $\mathrm{N}=13$ ) (Fig. 4). The plant

Tab. 3. Records of eggs (or larval webs) on S. columbaria in all localities during the pre and post-diapause period in the surveys 2012-2013, 2013-2014, 2014-2015 and 2015-2016.

\begin{tabular}{|c|c|c|c|c|c|c|}
\hline Patches & Survey & Plants (N) & $\begin{array}{l}\text { Plants with eggs } \\
\text { or pre-diapause } \\
\text { larval webs (N) }\end{array}$ & $\begin{array}{c}\text { Plant occupancy } \\
(\%)\end{array}$ & $\begin{array}{c}\text { Plants with } \\
\text { post-diapause } \\
\text { larval webs }(\mathrm{N})\end{array}$ & $\begin{array}{c}\text { Larval web } \\
\text { survival rate } \\
(\%)\end{array}$ \\
\hline 1 & 2013-14 & 66 & 1 & 1 & 1 & 100 \\
\hline 1 & $2014-15$ & 65 & 2 & 3 & 2 & 100 \\
\hline 1 & 2015-16 & 385 & 9 & 2 & $*$ & $*$ \\
\hline 2 & 2012-13 & 1000 & 20 & 2 & 0 & 0 \\
\hline 3 & 2012-13 & 714 & 2 & 0.3 & 0 & 0 \\
\hline 4 & 2013-14 & 50 & 1 & 2 & 0 & 0 \\
\hline 4 & $2015-16$ & 483 & 5 & 1 & $*$ & $*$ \\
\hline 12 & $2012-13$ & 929 & 1 & 0.1 & 0 & 0 \\
\hline Tot./Mean & & 3692 & 41 & 1 & 3 & $11^{* *}$ \\
\hline
\end{tabular}

Habitat patches (Fig. 1): 1, 4, Crossroads Santa Maria del Monte - Fonte Brignola; 2,3, Fonte Perara; 12, Hairpin curve Mattano - Malepasso. $\left(^{*}\right)$ The larval web survival rate was not calculated due to the 2015-2016 generation is yet in development. (**) The mean value was calculated excluding the larval webs of 2015-2016 generation. 
occupancy rate by egg batches differs in value between the host plant species (Tab. 2); it was considerably higher on: G. cruciata ( $60 \%$, Chi square test, $\mathrm{N}=561$, $\chi^{2}=232.216$; d.f. $\left.=1, \mathrm{P}<0.0001\right)$ when compared with $S$. columbaria $(2 \%)$ in the study areas; where $C$. leucantha and $S$. columbaria occur together in area $14, C$. leucantha is used preferentially ( $28 \%$, Chi square test, $\mathrm{N}=45$, $\chi^{2}=5859$; d.f. $\left.=1, \mathrm{P}=0.0155\right)$ compared with $S$. columbaria $(0 \%)$ in habitat patch 14 (Fig. 1).

Host plant use over three years. From 2013 to 2015 sixteen plants of $G$. cruciata ( $81 \%$ ) were used for oviposition and out of these $31 \%$ were used in two or three consecutive years (Fig. 5). The data from the

Tab. 4. Records of eggs (or larval webs) on G. cruciata and C. leucantha in all localities during the pre and post-diapause period in the surveys 2012-2013, 2013-2014, 2014-2015 and 2015-2016.

\begin{tabular}{|c|c|c|c|c|c|c|c|}
\hline & Patches & Survey & Plants (N) & $\begin{array}{l}\text { Plants with } \\
\text { eggs or } \\
\text { pre-diapause } \\
\text { larval webs (N) }\end{array}$ & $\begin{array}{l}\text { Plant } \\
\text { occupancy } \\
(\%)\end{array}$ & $\begin{array}{l}\text { Plants with } \\
\text { post-diapause } \\
\text { larval webs } \\
\text { (N) }\end{array}$ & $\begin{array}{l}\text { Larval web } \\
\text { survival rate } \\
(\%)\end{array}$ \\
\hline \multirow[t]{21}{*}{ Gentiana cruciata } & 2 & $2012-13$ & 1 & 1 & 100 & 0 & 0 \\
\hline & 3 & $2012-13$ & 11 & 6 & 54 & 5 & 83 \\
\hline & 3 & 2014-15 & 11 & 7 & 64 & - & - \\
\hline & 4 & $2015-16$ & 1 & 1 & 100 & & $*$ \\
\hline & 5 & 2014-15 & 9 & 5 & 55 & 2 & 50 \\
\hline & 5 & $2015-16$ & 7 & 3 & 43 & & * \\
\hline & 6 & $2014-15$ & 5 & 2 & 40 & 1 & 50 \\
\hline & 6 & 2015-16 & 5 & 3 & 60 & & * \\
\hline & 7 & 2015-16 & 14 & 13 & 93 & & $*$ \\
\hline & 8 & $2015-16$ & 14 & 5 & 36 & & $*$ \\
\hline & 9 & 2015-16 & 5 & 3 & 60 & & $*$ \\
\hline & 10 & $2015-16$ & 2 & 1 & 50 & & $*$ \\
\hline & 11 & $2015-16$ & 6 & 5 & 83 & & * \\
\hline & 12 & $2012-13$ & 7 & 6 & 86 & 2 & 33 \\
\hline & 12 & $2013-14$ & 7 & 3 & 43 & 3 & 100 \\
\hline & 12 & 2014-15 & 7 & 4 & 57 & 1 & 25 \\
\hline & 12 & $2015-16$ & 7 & 3 & 43 & & $*$ \\
\hline & 13 & 2013-14 & 9 & 3 & 33 & 2 & 67 \\
\hline & 13 & $2014-15$ & 9 & 1 & 11 & 1 & 100 \\
\hline & 13 & $2015-16$ & 9 & 5 & 55 & & $*$ \\
\hline & Tot./Mean & & 146 & 80 & 55 & 17 & $45^{* *}$ \\
\hline \multirow[t]{3}{*}{ Cephalaria leucantha } & 14 & $2014-15$ & 32 & 2 & 6 & 0 & 0 \\
\hline & 14 & $2015-16$ & 18 & 5 & 28 & & $* *$ \\
\hline & Tot./Mean & & 50 & 7 & 14 & & \\
\hline
\end{tabular}

Habitat patches: 1, 4, Bivio Santa Maria del Monte - Fonte Brignola; 2, 3, Fonte Perara; 5, 6, 7, 8, 11, along the path between the road to Santa Maria del Monte and Hairpin curve Mattano-Malepasso; 9, 12, 13, Hairpin curve Mattano-Malepasso; 10, Pian Mattano (Fig. 1); 14, Villa Camponeschi. (-) Lack of data due to the stationing of livestock that blocked the access to locality3 during 2014-15 survey. (*) The larval web survival rate was not calculated due to the 2015-2016 generation is yet in development; out of eighty plants of G. cruciata with eggs (or prediapause larval webs), only thirty were used in the data analysis; $(* *)$ The larval webs survival rate could not be defined for the five cases on C. leucantha because the 2015-2016 generation is yet in development. 
2012-2013 survey includes records of egg batches on the same two plants of $G$. cruciata for four successive years. The plants of G. cruciata without eggs were located in areas, which were in shadow or covered by vegetation and so not available for females.

Larval host plants during pre-diapause phase. Females of E. a. provincialis laid the eggs on their host plants when these plants were in full growth and flowering. After hatching, we recorded larvae mainly feeding on leaves of G. cruciata, rosette leaves and cortex of stems of $S$. columbaria, and leaves of $C$. leucantha and L. caprifolium.

The number of $S$. columbaria plants with egg batches, or used in summer by pre-diapause larval webs, was generally very low compared to the large number of plants recorded in all habitats patches and surveys (pre-diapause plant occupancy range: 0.1 $3 \%$, mean value, $1 \%$, Tab. 3). In G. cruciata, virtually all the available plants carried egg batches (or pre-diapause larval webs), even if this plant was uncommon at a site (noting that all G. cruciata plants were sampled). There were far fewer plants of $G$. cruciata (range: 1-14 plants) compared to $S$. columbaria (range: 50-1000 plants) and the pre-diapause G. cruciata occupancy was on average higher (ranges from $11 \%$ to $100 \%$, mean value: $55 \%$, Tab. 4) than that on S. columbaria (mean value, $1.11 \%$, Tab. 3) (Chi square test: $\chi^{2}=1308.134$, d.f. $=1, \mathrm{~N}=3838$, $\mathrm{P}<0.0001)$. The same pattern is seen in $C$. leucantha

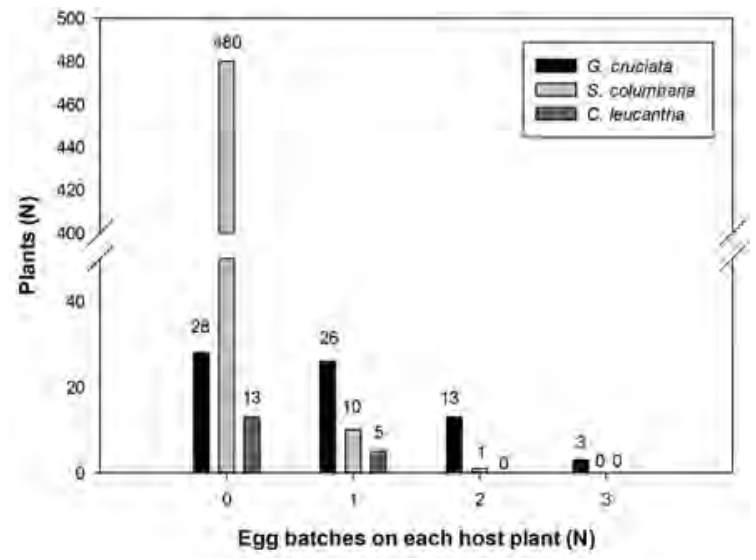

Fig. 4. Egg depositions on each host plants focusing on multiple events.
(Tab. 4) (Chi square test: $\chi^{2}=2637$, d.f. $=1, \mathrm{~N}=77$, $\mathrm{P}=0.1044)$.

Furthermore, whilst the larvae will eat any suitable host plant, even moving from one plant species to another when feeding (from G. cruciata to $S$. columbaria, from G. cruciata to L. caprifolium, from $S$. columbaria to L. caprifolium), in the wild the change of host plant is a random event caused by the total consumption of the plant by caterpillars. Larvae from eggs laid on G. cruciata and C. leucantha almost always complete their development on the same plant. In the rare circumstances where the larvae did need to move this was usually to the more abundant $S$. columbaria. Egg batches that were laid on S. columbaria rapidly consume the host plant due to its small size and are forced to move in search for a new food source; this is usually another plant of $S$. columbaria due to the abundance of this host compared to G. cruciata. The use of different host plants and the fact that all can act as interchangeable resources for larvae of E. a. provincialis were confirmed by our feeding tests in laboratory. In fact, larvae (I-VI instar) fed on all host plants that were offered during trials without showing any preference for the host species.

Larval host plants during diapause phase. In the end of summer, when larvae of $E$. aurinia provincialis started the winter diapause inside larval webs, the host plants $G$. cruciata and C. leucantha dried out, while L. caprifolium began to lose their leaves as winter ap-

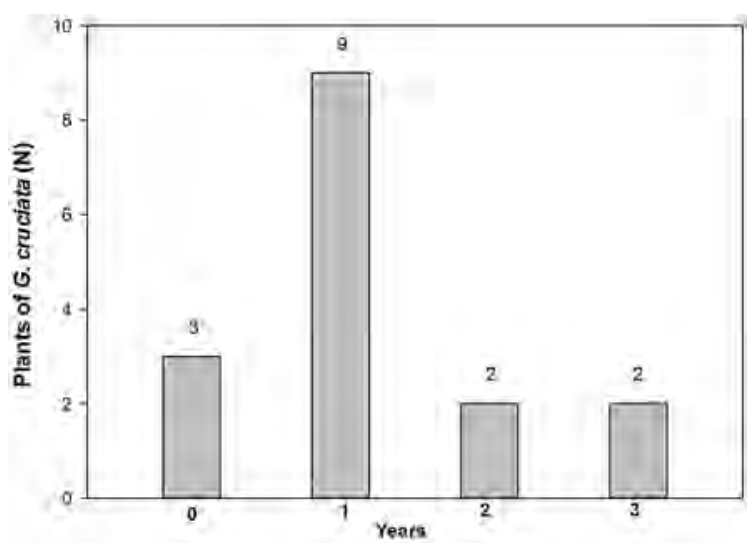

Fig. 5. Deposition frequencies on the same plant $G$. cruciata from generation to generation (2013-2014, 2014-2015 and 2015-2016) in the habitat patches 12 and 13 . 
proached. In contrast, $S$. columbaria retains a basal rosette of green leaves through the winter. In all habitats patches we observed overwintering larvae in large larval webs on G. cruciata and with small larval webs on other host plants. Additionally, larvae could enter diapause after spinning larval webs on other plants that were not host plants, e.g. leaves of grasses, Carlina acaulis L., Eryngium sp., Prunus spinosa L. and Sanguisorba minor Scop.

The larval webs on non-host plants were always recorded in two circumstances, i) during early larval stages, when larvae move from a host plant to another in search of new food and spin webs as part of dispersal, and ii) after moulting from III to IV instar when the larvae spin stronger webs in which to hibernate; these webs can be made on any adjacent vegetation. These observations suggest that the non-host plants may have been erroneously recorded as food sources in past studies.

\section{Larval host plants during post-diapause phase.}

After the winter, the emergence of larvae from diapause is dependent upon climatic conditions and therefore altitude and sun exposure. By February the fourth instar larvae are actively basking and looking for food. Each species of host plant differs in when they begin to grow fresh leaves and develop sufficiently to provide a viable food source for the larvae of $E$. a provincialis. In February, G. cruciata and C. leucantha are still dormant and only beginning to sprout new leaves; L. caprifolium is still leafless, while $S$. columbaria has new shoots on small rosettes and an abundance of leaves. In early February the surviving larval groups of IV instar larvae on G. cruciata were still gregarious but they did not live inside a silk larval web.

From February to April, larvae abandoned the original larval webs and moved onto nearby plants, usually $S$. columbaria plants, that were abundant and had shoots and leaves that larvae can eat. The rarity of the small shoots of other host plants is such that we never found gregarious larvae (IV instar) feeding on plants other than S. columbaria. During these transfers the larvae follow silken "guide strands" spun by lead caterpillars without having to build a larval web.

After emergence from diapause, the larvae gradually disperse into small groups and can even feed as solitary larva in IV instar. In March, when L. caprifolium produces new leaves on prostrate branches, larvae in $\mathrm{V}$ instar (all solitary) also started to feed on this host plant. As growth develops on G. cruciata, the $\mathrm{V}$ and VI instar larvae used all three host plants as food source (S. columbaria, L. caprifolium and G. cruciata) in the study area, although the majority still used $S$. columbaria. L. caprifolium and G. cruciata were used less frequently (Chi square test: $\chi^{2}=22.231$, d.f. $=2$, $\mathrm{P}<0.0001$ ). Out of forty-six larvae, $65 \%$ were recorded on S. columbaria, $24 \%$ on L. caprifolium and $11 \%$ on G. cruciata (Tab. 5).

During the journey from one plant to another, the caterpillars often stopped to bask in the sun on a silky "platform" which is spun on dry leaves on the ground. Basking enables larvae to metabolise food more rapidly than air temperatures would suggest they spend much of their time on non-feeding activities ( $\mathrm{z}$ score test: $\mathrm{z}=-3.7976, \mathrm{P}=0.00014)$. We observed a total of one hundred and thirty nine solitary larvae during the three seasons 2012-2015: only 33\% were involved with feeding behaviour and the rest in non-feeding types of behaviour (moving, 12\% and dorsal basking, 55\%) (Tab. 5).

When it was sunny, larvae arranged themselves in a single layer, more or less parallel to one another, on dead leaves (Fig. 2H), closing ranks when possible. When there was no sun (most of the day and night), larvae took shelter among the leaves and dried herbs and piled up on each other in a compact "ball" thus the contact surfaces between larvae increased as much as possible and reducing heat loss (Fig. 2I). This sec-

Tab. 5. Activities and host plants in solitary larvae (V e VI instar) of E. a. provincialis.

\begin{tabular}{|c|c|c|c|c|c|}
\hline Activity & Larvae (n) & $\%$ & Feeding on host plant & Larvae (n) & $\%$ \\
\hline Feeding & 46 & 33 & S. columbaria & 30 & 65 \\
\hline Moving & 16 & 12 & L. caprifolium & 11 & 24 \\
\hline Dorsal basking & 77 & 55 & G. cruciata & 5 & 11 \\
\hline Tot. & 139 & 100 & Tot. & 46 & 100 \\
\hline
\end{tabular}


ond behaviour, unknown in literature, was displayed by all gregarious caterpillars of fourth instar.

Larval web survival. Not all larval webs survived winter diapause and many individuals probably died (Tabs. 3 and 4). Out of forty-one egg/larval webs on $S$. columbaria that were recorded during all surveys only three overwintered giving a mean larval web survival rate equal to $11 \%$ (Tab. 3). Conversely, the larval web survival rate on G. cruciata was usually high in value and varied from 25 to $100 \%$ (Tab. 3). We found a difference between the two host plants in larval survival rate approaching significance level (Chi square test: $\chi^{2}=2871$, d.f. $\left.=1, \mathrm{~N}=121, \mathrm{P}=0.09\right)$.

Gregarious and solitary larval stages. During our observations on larvae feeding behaviour in February we recorded groups of IV instar larvae simultaneously with solitary larvae nearby. In March, all larvae were solitary and according to Wahlberg (2000) would have to be already at VI stage, but surprisingly they were still quite small. By collecting some of these larvae $(\mathrm{N}=27)$ and monitoring their growth up to pupa in captivity we revealed that twenty-four individuals were at $\mathrm{V}$ instar.

\section{DisCUSSION}

Host plants. There are over twenty larval host plants reported in literature for the Marsh fritillary $\mathrm{Eu}$ phydryas aurinia across its European range (Tab. 1). Among host plants, Cephalaria leucantha is mentioned as the host plant of the pre-imaginal stages in E. a. provincialis by Jutzeler (1994) and in E. a. aurinia by Mazel (1982, 1984); Gentiana cruciata is cited alone or together with Scabiosa columbaria or other plants by several authors (Mazel \& Lutran In: Jutzeler, 1994; Hafner, 2001 com. pers. In: Anthes, 2002; Perru \& Sardet, 2005; Sardet \& Betremieux, 2006; Lobenstein, 2008; Svitra \& Sielezniew, 2010). Lonicera caprifolium is reported as host plant of all subspecies of E. aurinia, except provincialis ssp., by Mazel (1977, in Jutzeler, 1994).

In Central Italy, our observations on E. a. provincialis show that four species of plant are used by larvae as host plants: Gentiana cruciata, Scabiosa columbaria, Lonicera caprifolium and Cephalaria leucantha. The larvae show no preference between these plants. These host plants are consumed by caterpillars from I to VI instar but the role played by each host plant in supporting larval growth is different and depends on vegetative status of each host plant species. The mean values of plant occupancy showed that: G. cruciata $(55 \%)$ and C. leucantha $(14 \%)$ prevail in the diet of the pre-diapause larval stages (Tab. 4 ), with $S$. columbaria providing the major food source for the post-diapause fourth instar $65 \%$ to the nourishment of the fifth and sixth instar. L. caprifolium provides a lesser contribution as a food source for the V-VI instars (24\%, Tab. 5).

In laboratory larvae did eat Gentiana lutea, no eggs or larvae were found using this host plant in the wild.

Oviposition host species. Females laid their eggs on three plant species, Gentiana cruciata, Scabiosa columbaria and Cephalaria leucantha (Tabs. 2-4). Whenever S. columbaria and G. cruciata coexist, the pre-diapause plant occupancy on G. cruciata is on average higher than that on S. columbaria (Tab. 3) although G. cruciata is uncommon at a site (noting that all G. cruciata plants were sampled) and S. columbaria was very abundant. The same pattern was seen where C. leucantha is together with $S$. columbaria. Why do the females lay more egg batches on plants that are less frequent and numerically rare? In E. aurinia, the main stimulus that encourages females to alight on a plant is primarily visual, as observed in $E$. editha (Ehrlich \& Hanski, 2004). Therefore, the visibility of plants is crucial in selecting oviposition sites and depends on local features of the soil morphology, the vegetation structure, and the physical size of the host plant present within a habitat patch. This topic has been studied by several authors and recognized as related to the presence of eggs (Porter, 1981; 1982; 1992; Anthes et al., 2003; Konvicka et al., 2003; Fowles \& Smith, 2006; Liu et al., 2006; Stefanescu et al., 2006; Betzholtz et al., 2007; Botham et al., 2011; Pennekamp et al., 2013).

Our observations on E. a. provincialis have led us to the same conclusion and show that there was no preference in the choice of the host plant in this species and the egg deposition was determined only by host plants visibility and accessibility to females. Females of E. a. provincialis mainly laid their eggs on G. cruciata (and on C. leucantha) that are more easily accessible than $S$. columbaria (Fig. 3) although those plants were much less numerous than those of $S$. columbaria (about 1:100). Taking into account the egg 
batches alone, the plant occupancy rate were higher: $60 \%$, G. cruciata, $28 \%$, C. leucantha, $2 \%$, S. columbaria, in each habitat patches (Tab. 2). This shows a distinct preference for the large, clearly accessible plants of $G$. cruciata. We want to emphasize that $C$. leucantha does not exist in the same place with $G$. cruciata; C. leucantha is limited to a rocky slope in a small habitat patch nearby Villa Camponeschi therefore it is not ecologically relevant to compare cruciata with leucantha.

Considering the presence of eggs and larval webs together, although different factors (i.e. mortality, starvation, etc.) can affect the conclusions above, a similar pattern in host plant use is observed $(55 \%$, G. cruciata, 14\%, C. leucantha, 1\%, S. columbaria (Tabs. 3 and 4). During the flight period of E. $a$. provincialis the vegetative status of the host plants and surrounding vegetation was systematically recorded. This could provide an approximate index of the visibility of the host plant.

In all altitudinal zones in the study area $\mathrm{G}$. cruciata is represented by prominent, large-sized individuals that stand out clearly above the surrounding vegetation. The ground rosettes leaves of $S$. columbaria are almost always completely hidden, and therefore inaccessible to searching females. In north-facing and wet grassland patches, $S$. columbaria is very frequent but patchily distributed and completely hidden by the surrounding tall grasses, with the flower heads of S. columbaria concealed by vegetation (Fig. 3A). In these places there are neither webs nor eggs despite the local high host plant density. On contrast, the eggs batches are found on $S$. columbaria where slope, aspect, sun exposure, humidity and soil, do allow good visibility of host plants. In these situations the host plants may be larger in size, or more apparent due to grazing activity.

Some authors suggest that the presence of egg batches is linked to host plant density and other factors such as host plant size, morphology and growth habits, and vegetation structure of the habitat (Anthes et al., 2003; Fowles \& Smith, 2006; Liu et al., 2006; Stefanescu et al., 2006; Betzholtz et al., 2007), or microclimatic predictors (sun exposure and topography, Botham et al., 2011; Pennekamp et al., 2013). Our observations are not inconsistent with those results. In fact, the egg and larval occupancy of $S$. columbaria is very low in all habitat patches, both where large and small host plants coexist, and where only small plants are present.
Some plants of G. cruciata, even if visible and accessible for females, occur in shady or dense vegetation cover. These plants were never used for egg laying in contrast to plants in open sunny conditions that held egg batches year after year (Fig. 5). These results show how the location (sun exposure, microclimate) of plants of the same species can influence the female choice of oviposition site. In addition, the exposure to sunlight within the habitat could shape the female choice for oviposition plant; for example, large, visible plants would not be considered for egg laying if they were in shadow. For this reason there were plants that were highly visible, but shaded, on which egg batches were never observed compared to "optimally" placed plants that were used for oviposition for consecutive seasons (Fig. 5). The observed pattern of host plant use is of great relevance to the conservation of the species $E$. a. provincialis, with the data showing selection of the same $G$. cruciata plants year after year. Accordingly to observations on E. a. aurinia (Porter, 1992; Anthes et al., 2003; Sardet \& Betremieux, 2006; Singer, 2003 In: Stefanescu et al., 2006) females of $E$. a. provincialis also lay their eggs on the same plant where other females have previously laid. The multiple batch placements seem unrelated to host plant availability. In the study area there were many plants without egg batches $(40 \%$, G. cruciata, $\mathrm{N}=70 ; 97 \%$, S. columbaria, $\mathrm{N}=396$ ) (Fig. 4). In fact, females seemed to prefer the plants with egg batches rather than "empty" ones despite these being available. The presence of eggs as a stimulant for further egg batches being added is known in other butterflies (Ehrlich \& Hanski, 2004). In E. a. provincialis the presence of multiple egg laying events on the same plant could not be random because during oviposition behaviour the females make a long and meticulous inspection of the host plant and then lay their eggs nearby or on the egg batches laid previously by a different female (Fig. 2C). If this inspection of host plants was aimed at preventing the competition for trophic sources, females would avoid laying on host plants that already held batches. The hypothesis that the multiple egg laying events on the same host plant can be due to the lack of host plants is unsupported. For example, excluding the plants located in non-optimal conditions for butterfly activity, a moderate percentage of Gentian plants were not used by females.

Given the above, why do females oviposit on small plants and not continue to search for large host 
plants? We think that females of E. a. provincialis do not use size in selecting host plants, but they oviposit on the first host plant found during their search; then, they check it, not to evaluate the plant (prerequisite for a choice whether or not to abandon it) rather to search for eggs laid by other females before adding their batch. Although this female behaviour is seemingly not favourable for larvae in terms of competition for food source, it provides benefits in terms of survival by creating large numbers within a feeding group during the post-diapause stages (see below).

Larval host plant choice. Pre-diapause and diapause phase. The young larvae (I-III instars) have a distinct behaviour and live in a group inside a silk larval web feeding on the four above-mentioned plants. The key point is that, accordingly to the data on egg batches, large plants were mostly occupied by the pre-diapausing stages. In the study area, the pre-diapause plant occupancy on $G$. cruciata was on average always higher than that on S. columbaria (respectively, $55 \%$ vs. $1 \%$, Tabs. 3 and 4). This was also true in the habitat patches nearby Villa Camponeschi where G. cruciata is absent and $C$. leucantha takes over as large sized host plant; here, the plant occupancy on C. leucantha was $14 \%$ and higher than that on $S$. columbaria (on this plant no larval web was observed). This suggests that, when eggs laying occurred on large-sized plants, the young caterpillars remain aggregated, thanks to the abundance of food provided by plant. These larvae also built large, robust larval webs, spun around two or three stems of host plant, that easily withstood the ravages of winter (Fig. 2D,E). These larval webs may contain some hundreds of larvae. In contrast, if egg laying occurred on small host plants, such as the rosettes of $S$. columbaria, the larvae quickly consumed the whole plant and then were forced to move onto new food sources. In these cases, the original feeding group of larvae dispersed in the meadows and often divided into small groups, not all of which survived due to starvation (see below in Larval survival paragraph). The surviving larvae made small and less robust larval webs (Fig. 2F) and these contained a small numbers of individuals. Only two examples were found where this also occurred on G. cruciata where larvae consumed the original host plant and the original gregarious group dispersed as they searched for a new food source. The overwintering larval webs were recorded on the four host plants cited above and also on some Graminacee and other plants as Carlina acaulis, Eryngium sp., Prunus spinose, Sanguisorba minor.

Post-diapause phase. After the diapause period, in February, gregarious larvae (IV instar) became active; they moved on the ground in search of food, using a silk thread to guide the group of caterpillars. In February, available food consisted solely of small but abundant shoots of $S$. columbaria, with minimal contribution from small shoots of the few plants of $G$. cruciata and $C$. leucantha (Fig. 3). The plants of $L$. caprifolium are, at this time of year, without leaves and cannot be used as a food source. From March onwards, the fifth instar larvae were feeding as individuals with no gregarious behaviour and start to utilise L. caprifolium as it produces fresh leaves and shoots. In the study area all three host plants provided food source for E. a. provincialis caterpillars post-diapause, but with S. columbaria as main food source (Tab. 5).

Larval survival after winter diapause. It is clear that the larger host plants have an important role in the larval development during the pre-diapause period and reduce winter mortality during the early larval instars and a high survival through the winter (diapausing larvae).

The survival rate of overwintering larval webs on G. cruciata was on average higher than on S. columbaria, though not reaching significance. This result becomes more significant when the differences in web size are considered; although this rate was impossible to determine directly without causing irreparable damage to the larval webs, it was easily inferable as the larval webs on G. cruciata and C. leucantha contained many more larvae (150-200 larvae) than those on the S. columbaria (20-50 individuals). The better survival rate on G. cruciata can be related two points: the size and biomass of G. cruciata and the benefits of large overwintering webs. The large plant size and abundant leaves of $G$. cruciata, enable the first three larval instars to develop on a single host plant. This means that larvae do not need to disperse in search of food in contrast to larvae using small plants as S. columbaria. The high numbers of larvae on G. cruciata are able to construct large and robust larval webs (a larval web on gentian: $10-15 \mathrm{~cm}$ in length and $4-5 \mathrm{~cm}$ in diameter), which provide protection from climatic pressures (snow, rain, low temperatures) and predators. The predators includes true bugs (Hemiptera, Heteroptera) as Deraeocoris schach (Fabricius, 1781) (Pinzari, 2016) and Picromerus bidens (L., 1758) that attack the pre- 
diapause larvae, and flies Erycia furibunda (Zetterstedt, 1844) (Diptera, Tachinidae) that are parasitoid of the pre-diapause larvae (Pinzari, in press).

At this point, it is legitimate to ask why $E$. $a$. provincialis continues to egg lay on $S$. columbaria if it seems to be advantageous in terms of larval survival to oviposit on G. cruciata and large plants in general. Our results show that, on their own, large plants of $G$. cruciata do not ensure the survival of E. a. provincialis larvae as they are unavailable as a food source for postdiapause larvae. S. columbaria and L. caprifolium are key sources of food during the post-diapause period. Additionally, in patches where G. cruciata was absent, the larval webs survival of E. a. provincialis was exclusively dependent upon S. columbaria and L. caprifolium, although with low survivorship.

Post-diapause larval activities and thermoregulation. The fact the shoots of small plants were the main food source for larvae during the post-diapause period means that they need to move frequently to find food. This is facilitated by the high density of $S$. columbaria plants but also includes opportunities to bask. This matches Porter's studies (1982) where larvae need an optimum body temperature (not less than $30^{\circ} \mathrm{C}$ ) to metabolize food efficiently. When they feed their body temperature decreases for the ingestion of cold food; consequently, they need to bask in sunshine to raise their body temperature above $30^{\circ} \mathrm{C}$. In February, the temperatures reached as low as $0^{\circ} \mathrm{C}$ and never exceed $10-15^{\circ} \mathrm{C}$ until April. Consequently, it is easy to understand how, at low temperatures, it is difficult for caterpillars to maintain the optimum body temperature for rapid food digestion and how long periods of dorsal basking are needed to (especially in the fourth instar) to facilitate rapid digestion. The results of our observations on the fifth and sixth solitary caterpillars activities do show that around $55 \%$ of their time is devoted to body thermoregulation compared the time spent moving or feeding (Tab. 5).

In E. a. aurinia, larvae use dorsal basking behaviour to heat up in the sun and raising their body to temperatures above $30^{\circ} \mathrm{C}\left(35-37^{\circ} \mathrm{C}\right)$ (Porter, 1982). The change of larval habitus from pale-brown in postdiapause feeding stages to jet-black in post-diapause is presumably related to individual body thermoregulation. The colour helps both absorbing the solar radiation and limit heat losses. Porter (1982) showed that the larval body temperature decreases as they feed low down in the cooler parts of the plant and suggested that larvae move closer together to reduce the lateral dispersion of heat. This behaviour was also observed during our field work; when it was sunny, larvae arranged themselves more or less parallel in tightly aligned groups and in a single layer (Fig. 2H). Additionally, we observed another behaviour used by caterpillars for reducing heat loss from their body in absence of sun (in cloudy days or at sunset). At these times larvae took shelter among the leaves and dried herbs and piled up on each other in a tight, almost spherical cluster, thus the larvae are in close contact with all their neighbours and this will reduce heat loss from each larva (Fig. 2I). The basking and clustering behaviours are reinforced by the female behaviour of adding eggs to existing batches to create larger groups of larvae. This preference to lay eggs on a plant with existing egg batches will have evolutionary advantage. The aggregation of individuals is an effective way to promote warming, and the greater the number of larvae in a group the better. Hence, multiple egg deposition on the same host plant and large larval webs on large host plants give greatest advantage to survival of larvae.

As spring progresses, the climatic conditions change and temperatures rise. In these conditions gregarious behaviour is not needed as a way of maintaining the temperature body; the need to find new food sources is now more important than the need to keep warm by group basking. At this time the fresh shoots of host plants are soon exhausted as the larvae grow larger, and larval groups begin to split up to search for new food sources. By the fifth instar the gregarious behaviour ceases and larvae become solitary.

\section{CONCLUSIONS}

Females of E. a. provincialis oviposit on three host plants (G. cruciata, S. columbaria, C. leucantha) without any preference and locate them by using visual stimuli. More visible and accessible plants $(G$. cruciata and $C$. leucantha) show a higher number of egg laying events.

Female prefer to lay their eggs on the plants where other females have previously oviposited as in E. aurinia aurinia (Porter, 1992; Anthes et al., 2003; Sardet \& Betremieux, 2006; Singer, 2003 In: Stefanescu et al., 2006). In E aurinia, living in larval groups seems to be evolutionary selected through laying egg batches. Double and triple egg laying events on the same plant contribute to form single, large 
groups of larvae. This female behaviour can be seen as disadvantageous because of the high competition for food sources among young larvae on the same host plant; however, gregarious behaviour can offer several benefits to larvae during both pre-diapause period and post-diapause period.

E. a. provincialis is a polyphagous species in the study area. The larvae feed on three plants G. cruciata, L. caprifolium and S. columbaria, and in other patches nearby our study area they also eat $C$. leucantha. A fifth species, G. lutea is eaten under laboratory conditions but needs further confirmation in the wild. The larvae show no preference for a specific host plant, readily moving from one to another one when feeding. All host plants are important for the larval survival in $E$. a. provincialis, supporting their growth and development during one or more of their larval stages.

The success of E. a. provincialis and its persistence over forty years in the study area may be helped by the larvae being polyphagous. The preferential use of different host plants by larvae at each growth stage ensures the survival of the species.
Larval survival is often the key determinant of population size and distribution, so understanding the sources and variation in larval mortality is essential to understanding and predicting butterfly population dynamics.

\section{ACKNOWLEDGMENTS}

The present study is a part of the projects of the Osservatorio per la Biodiversità del Lazio (OBL), coordinated by the senior author (VS) at the Department of Biology, Tor Vergata University of Rome on behalf of the Assessorato Ambiente e Cooperazione tra $\mathrm{i}$ Popoli della Regione Lazio and intended to provide guidelines to help monitor species protected under the Habitat Directive 92/43/CEE (Art. 17, par. 1). We would like to thank Anna Appolloni and Giuseppe Farina for their help in the field work; Arch. Valeria Pinzari for her graphic support; Dr. Stefano Valente for the identification of some plants. Finally, we are very grateful to Dr. Keith Porter (Natural England, UK) for his helpful comments on the original submission and language review of the final version.

\section{REFERENCES}

Anthes N., 2002 - Lebenszyklus, habitatbindung und Populationsstr Englandtur des Goldenen Scheckenfalters Euphydryas aurinia Rott. Im Alpenvorland. Diplomarbeit Westfalische Wilhelms-Universität Münster, 87 pp.

Anthes N., Fartmann T., Hermann G., KaUle G., 2003 - Combining larval habitat quality and metapopulation structure, the key for successful management of pre-alpine Euphydryas aurinia colonies. Journal of Insect Conservation, 7: 175-185.

Balletto E., Cassulo L.A., 1995 - Lepidoptera Hesperioidea, Papilionidea. In: Minelli A., Ruffo S., La Posta S. (eds.), Checklist delle specie della fauna italiana, 89. Calderini, Bologna.

Balletto E., Bonelli S., Zilli A., 2014a - Lepidotteri. In: Genovesi P. et al. (eds), Specie e habitat di interesse comunitario in Italia: distribuzione, stato di conservazione e trend. Rapporti ISPRA.

Balletto E., Cassulo L., Bonelli S., 2014b - Annotated Checklist of the Italian Butterflies and Skippers (Papilionoidea, Hesperiioidea). Zootaxa, 1: 1-114.

Betzholtz P.E., Ehrig A., Lindeborg M., Dinnetz P., 2007 - Food plant density, patch isolation and vegetation height determine occurrence in a Swedish metapopulation of the marsh fritillary Euphydryas aurinia (Rottemburg, 1775) (Lepidoptera, Nymphalidae). Journal of Insect Conservation, 11: 343-350.

Bonelli S., CerRato C., Loglisci N., Balletto E., 2011 - Population extinctions in the Italian diurnal Lepidoptera: an analysis of possible causes. Journal of Insect Conservation, 15: 879-890.

Botham M.S., Ash D., Aspey N., Bourn N.A.D., Culman C.R., Roy D.B., J. Swain, Zannese A., Pywell R.F., 2011 - The effects of habitat fragmentation on niche requirements of the marsh fritillary, Euphydryas aurinia, (Rottemburg, 1775) on calcareous grasslands in southern England. Journal of Insect Conservation, 15: 269-277.

Casacci L.P., Cerrato C., Barbero F., Bosso L., Ghidotti S., Paveto M., Pesce M., Plazio E., Panizza G., Balletto E., VITERBI R., BonelLi S., 2014 - Dispersal and connectivity effects at different altitudes in the Euphydryas aurinia complex. Journal of Insect Conservation, 19(2): 265-277.

EeLes P., 2014 - Marsh Fritillary Euphydryas aurinia (Rottemburg) F. hibernica (Birchall) oviposition observations in Dublin, Ireland in 2013. Entomologist's Record and Journal of Variation, 126(1): 15-19. 
EHRLICH P.R., HANSKI I., (eds) 2004 - On the wings of checkerspots: a model system for population biology. Oxford University Press, Oxford, $371 \mathrm{pp}$.

FAVRETTO J.P., 2009 - Valeriana officinalis, a new plant host of Euphydryas aurinia (Rottemburg, 1775) (Lep. Nymphalidae). Oreina, 7: 7-9.

FORD H.D., Ford E.B., 1930 - Fluctuation in numbers, and its influence on variation, in Melitaea aurinia, Rott. (Lepidoptera). Transactions of the Royal Entomological Society of London, 78(2): 345-352.

Fowles A.P., Smith R.G., 2006 - Mapping the habitat quality of patch networks for the marsh fritillary Euphydryas aurinia (Rottemburg, 1775) (Lepidoptera, Nymphalidae) in Wales. Journal of Insect Conservation, 10(2): 161-177.

HARTig F., 1968 - Einige neue Lepidopterenrassen und -formen und eine wiederentdeckte Noctuide aus Süditalien. Reichenbachia, 12(1): 1-13.

Hula V., Konvicka M., Pavlicko A., ZdeneK F., 2004 - Marsh-Fritillary (Euphydryas aurinia) in the Czech Republic: monitoring, metapopulation structure, and conservation of an endangered butterfly. Entomologica Fennica, 15: 231-241.

Junker M., Wagner S., Gros P., Schmitt T., 2010 - Changing demography and dispersal behavior: ecological adaptions in an alpine butterfly. Oecologia, 164: 971-980.

JutZELER D., 1994 - Quelques observations de terrain sur l'ecologie d'Eurodryas aurinia ssp. provincialis (Boisduval, 1829) en Ligurie (Italia) et dans les Alpes-Maritimes (France) (Lepidopteres: Nymphalidae). Bulletin de la Société Entomologique de Mulhouse, 4: 77-81.

Klemetti T., Whalberg N., 1997 - Punakeltaverkkoperhosen (Euphydryas aurinia) ekologia ja populaatiorakenne Suomessa. Baptria, 22: 87-93.

KONVIČKa M., HULA V., Fric Z., 2003 - Habitat of pre-hibernating larvae of the endangered butterfly Euphydryas aurinia (Lepidoptera: Nymphalidae): what can be learned from vegetation composition and architecture? European Journal of Entomology, 100: 313-322.

KuUssaAri M., VAn Nouhuys S., Hellmann J.J., Singer M.C., 2004 - Larval biology of checkerspots. In: EhrLich P.R., HanSKi I. (eds), On the wings of checkerspots. A model system for population biology. Oxford University Press, Oxford, 371, pp. 138-160.

LiU W., WANG Y., XU R., 2006 - Habitat utilization by ovipositing females and larvae of the Marsh fritillary (Euphydryas aurinia) in a mosaic of meadows and croplands. Journal of Insect Conservation, 10(4): 351-360.

LoBENSTEIN U., 2008 - Life history of the marsh fritillary Euphydryas aurinia (Rottemburg, 1775) in the Weser region of Lower Saxony, Germany (Lepidoptera: Nymphalidae). Entomologische Zeitschrift, 118(5): 217-220.

LuCKENS C.J., 1978 - Euphydryas aurinia Rott. in Britain: notes on distribution and life history. Entomologist's Record and Journal of Variation, 90(4): 108-112.

MAZEL R., 1982 - Exigences trophiques et evolution dans les genres Euphydrias et Melitaea sensu lato (Lep. Nymphalidae). Annales de la Société Entomologique de France, 18(2): 211-227.

MAZEL R., 1984 - Trophisme, hybridation et speciation chez Eurodryas aurinia Rottemburg (Lepidoptera, Nymphalidae). Thèse d'Etat, Académie de Montpellier, Université de Perpignan, 335 pp.

MAZEL R., 2006 - Déterminisme et stratégie de choix des plantes hôtes chez Euphydryas aurinia Rott. (Lepidoptera, Nymphalidae). Revue de l'Association Roussillonnaise d'entomologie, 15(2): 78-83.

Parenzan P., Porcelli F., 2006 - I macrolepidotteri italiani Fauna. Lepidopterorum Italiae (Macrolepidoptera). Phytophaga, XV: $1-1051$.

Pennekamp F., Monteiro E., Schmitt T., 2013 - The larval ecology of the butterfly Euphydryas desfontainii (Lepidoptera: Nymphalidae) in SW-Portugal: food plant quantity and quality as main predictors of habitat quality. Journal of Insect Conservation, 17(1): 195-206.

Peńuelas J., Sardans J., Stefanescu C., Parella T., Filella I., 2006 - Lonicera implexa leaves bearing naturally laid eggs of the specialist Herbivore Euphydryas aurinia have dramatically greater concentrations of iridoid glycosides than other leaves. Journal of Chemical Ecology, 32: 1925-1933.

Perru S., Sardet E., 2005 - Biologie de la conservation de Maculinea rebeli Hirschke (Lepidoptera, Lycaenidae) et de sa plante-hote Gentiana cruciata L en region Lorraine (Nord-Est de la France). Linneana Belgica, XX(4): 123-134.

PINZARI M, 2016 - Deraeocoris schach, a new predator of Euphydryas aurinia and other heteropteran feeding habits on caterpillar web (Heteroptera: Miridae; Lepidoptera: Nymphalidae). Fragmenta entomologica, 48(1): 77-81. 
PinZARi M, PinZAri M, ZiLli A., 2010 - Deep lepidopterological exploration of Mt Cagno and surroundings (Central Italy), a restricted mountain massif and hotspot for butterfly and moth diversity (Lepidoptera). Bollettino dell'Associazione Romana di Entomologia, 65(1-4): 3-383.

Porter K., 1981 - The population dynamics of small colonies of the butterfly Euphydryas aurinia. PhD dissertation, Oxford University, UK.

PORTER K., 1982 - Basking behavior in larvae of the butterfly Euphydryas aurinia. Oikos, 38: 308-312.

Porter K., 1992 - Eggs and egg-laying. In: Dennis R.L.H. (ed.), The ecology of butterflies in Britain. Oxford University Press, pp. 46-72.

PORTER K., ElLIS S., 2011 - Securing viable metapopulations of the Marsh Fritillary butterfly, Euphydryas aurinia, (Lepidoptera: Nymphalidae) in Northern England. Journal of Insect Conservation, 15: 111-119.

Prola C., Provera P., Racheli T., Sbordoni V., 1978 - I Macrolepidotteri dell'Appennino Centrale. Parte I. Diurna, Bombyces e Sphinges. Fragmenta Entomologica, 14: 1-217

SAARINEN K., JANTUNEN J., VAltonen A., 2005 - Resumed forest grazing restored a population of Euphydryas aurinia (Lepidoptera: Nymphalidae) in SE Finland. European Journal of Entomology, 102: 683-690.

Sardet E., Betremieux P.A., 2006 - Distribution et conservation du Damier de la succise (Euphydryas aurinia) en Lorraine francaise (Lepidoptera, Nymphalidae). Linneana Belgica, 20(5): 163-179.

Stefanescu C., Peñuelas J., Sardans J., Filella I., 2006 - Females of the specialist butterfly Euphydryas aurinia (Lepidoptera: Nymphalidae: Melitaeini) select the greenest web leaves of Lonicera implexa (Caprifoliaceae) for oviposition. European Journal of Entomology, 103: 569-574.

Svitra G., Sielezniev M., 2010 - The first observation of Euphydryas aurinia (Lepidoptera, Nymphalidae) developing on Gentiana cruciata in Lithuania. Polish Journal of Entomology, 79: 195-201.

VAn SwaAy C.A.M., Warren M.S., 1999 - Red Data Book of European Butterflies (Rhopalocera). Nature and Environment Series No. 99. Council of Europe, Strasbourg. 260 pp.

Van Swayy C., Wynhoff I., Verovnik R., Wiemers M., López Munguira M., Maes D., Sasic M., Verstrael T., Warren M., Settele J., 2010 - Euphydryas aurinia. In: IUCN 2013. IUCN red list of threatened species. Version 2013.2. www.iucnredlist.org

Verity R., 1950 - Famiglie Apaturidae e Nymphalidae. In: Le Farfalle diurne d'Italia. Marzocco, Firenze, Vol. IV, Tav. 38-54, XV-XX, 380 pp.

WAHLBERG N., 2001 - The phylogenetics and biochemistry of host-plant specialization in Melitaeine butterflies (Lepidoptera: Nymphalidae). Evolution, 55(3): 522-537.

Wahlberg N., Kullberg J., Hanski I., 2001 - Natural history of some Siberian melitaeine butterfly species (Nymphalidae: Melitaeini) and their parasitoids. Entomologica Fennica, 12: 72-77.

WARREN M.S., 1993 - Observations on the use of honeysuckle (Lonicera periclymenum) as a natural food-plant of the Marsh Fritillary (Eurodryas aurinia) (Lepidoptera: Nymphalidae) in southern Britain. Entomologist's Gazette, 44: 241-244.

WARREN M.S., 1994 - The UK status and suspected metapopulation structure of a threatened European butterfly, the marsh fritillary Eurodryas aurinia. Biological Conservation, 67: 239-249.

Warren M.S., 1996 - Euphydryas aurinia. In: Van Helsdingen P.J., Willemse L.P.M., Speight M.C.D. (eds.), Background information on invertebrates of the Habitats Directive and the Bern Convention. Part I - Crustacea, Coleoptera and Lepidoptera: 121-126. Council of Europe, Strasbourg, Nature and environment, No. 79.

Warren M.S., Munguira M.L., Ferrin J., 1994 - Notes on the distribution, habitats and conservation of Eurodryas aurinia (Rottemburg) (Lepidoptera: Nymphalidae) in Spain. Entomologist's Gazette, 45: 5-12. 